\title{
Population susceptibility to North American and Eurasian swine influenza viruses in England, at three time points between 2004 and 2011
}

K Hoschler (katja.hoschler@phe.gov.uk) ${ }^{1}$, C Thompson ${ }^{1}$, I Casas $^{2}$, J Ellis ${ }^{1}$, M Galiano ${ }^{1}$, N Andrews ${ }^{3}$, M Zambon ${ }^{1}$

1. Public Health England, Microbiology Services Colindale, London, United Kingdom

2. National Centre for Microbiology, World Health Organization National Influenza Centre, Institute of Health Carlos III, Madrid, Spain

3. Public Health England, Health Protection Services Colindale, London, United Kingdom

Citation style for this article:

Hoschler K, Thompson C, Casas I, Ellis J, Galiano M, Andrews N, Zambon M. Population susceptibility to North American and Eurasian swine influenza viruses in England, at three time points between 2004 and 2011

Euro Surveill. 2013;18(36):pii=20578. Available online: http://www.eurosurveillance.org/ViewArticle.aspx?Articleld=20578

Age-stratified sera collected in 2004, 2008 and 2010 in England were evaluated for antibody to swine influenza $A\left(\mathrm{H}_{3} \mathrm{~N}_{2}\right)$ and $A\left(\mathrm{H}_{1} \mathrm{~N}_{1}\right)$ viruses from the United States or Europe as a measure of population susceptibility to the emergence of novel viruses. Children under 11 years of age had little or no measurable antibody to recent swine $\mathrm{H}_{3} \mathrm{~N}_{2}$ viruses despite their high levels of antibody to recent $\mathrm{H}_{3} \mathrm{~N}_{2}$ seasonal human strains. Adolescents and young adults (born 1968-1999) had higher antibody levels to swine $\mathrm{H}_{3} \mathrm{~N}_{2}$ viruses. Antibody levels to swine $\mathrm{H}_{3} \mathrm{~N}_{2}$ influenza show little correlation with exposure to recent seasonal $\mathrm{H}_{3} \mathrm{~N}_{2}$ (A/Perth/16/2009) strains, but with antibody to older $\mathrm{H}_{3} \mathrm{~N}_{2}$ strains represented by A/Wuhan/359/1995. Children had the highest seropositivity to influenza $\mathrm{A}\left(\mathrm{H}_{1} \mathrm{~N}_{1}\right)$ pdmog virus, and young adults had the lowest antibody levels to A/Perth/16/2009. No age group showed substantial antibody levels to A/Aragon/ $R_{R} 3218 / 2008$, a European swine $\mathrm{H}_{1} \mathrm{~N}_{1}$ virus belonging to the Eurasian lineage. After vaccination with contemporary trivalent vaccine we observed evidence of boosted reactivity to swine $\mathrm{H}_{3} \mathrm{~N}_{2}$ viruses in children and adults, while only a limited boosting effect on antibody levels to A/Aragon/RR3218/2008 was observed in both groups. Overall, our results suggest that different vaccination strategies may be necessary according to age if swine viruses emerge as a significant pandemic threat.

\section{Introduction}

Pigs are considered a mixing vessel for the reassortment of avian, swine and human influenza viruses. Recent events confirm their important role in the emergence of novel influenza viruses capable of causing a human pandemic [1]. Until the 1990s, classic swine influenza $A\left(\mathrm{H}_{1} \mathrm{~N}_{1}\right)$, the most commonly circulating swine influenza virus among pigs, remained genetically fairly constant [2]. However, by the late 1990s, different subtypes $\left(\mathrm{H}_{1} \mathrm{~N}_{1}, \mathrm{H}_{3} \mathrm{~N}_{2}\right.$ and $\left.\mathrm{H}_{1} \mathrm{~N}_{2}\right)$ had emerged and became predominant among North American pig herds [3]. These swine influenza $A$ viruses acquired avian, human, and swine virus gene segments through reassortment $[3,4]$ and various genetic lineages can be distinguished within each subtype [4]. In Europe, swine influenza is primarily caused by the aforementioned subtypes. However, their antigenic and genetic characteristics differ significantly from those found in North America and Asia [5,6]. Genetic diversity has been expanded through multiple introductions of influenza viruses from other animal hosts into pig herds, including from humans [7], most recently demonstrated with $\mathrm{A}\left(\mathrm{H}_{1} \mathrm{~N}_{1}\right)$ pdmog virus in Europe, Asia, and the Americas $[6,8,9]$.

For this study of population susceptibility we chose two swine virus subtypes which have most recently caused outbreaks or sporadic cases in humans. These include representatives of swine influenza $\mathrm{A}\left(\mathrm{H}_{3} \mathrm{~N}_{2}\right)$ viruses $\left(\mathrm{swH}_{3} \mathrm{~N}_{2}\right)$ recently isolated from human cases in the United States $[10,11]$ and a swine influenza $A\left(\mathrm{H}_{1} \mathrm{~N}_{1}\right)$ viruses $\left(\mathrm{swH}_{1} \mathrm{~N}_{1}\right)$ isolated from a zoonotic infection in Europe [12].

The primary objective of this analysis was the improvement of the risk assessment of population susceptibility to currently circulating swine influenza viruses, with the proven ability to cause zoonotic infections.

\section{Methods}

We measured haemagglutination inhibition ( $\mathrm{HI}$ ) antibody prevalence to representative current and previous seasonal $\mathrm{H}_{3} \mathrm{~N}_{2}$ and $\mathrm{H}_{1} \mathrm{~N}_{1}$ strains, to which the population of the United Kingdom (UK) has been exposed, and compared it with $\mathrm{HI}$ antibody reactivity to influenza $\mathrm{H}_{3}$ and $\mathrm{H}_{1}$ strains of swine origin to which the UK population is very unlikely to have been exposed. We also determined vaccine-induced cross-reactive antibodies in pre- and post-immunisation sera.

\section{Serum samples}

We used a random selection of anonymised agestratified residual serum aliquots collected in England 
[14] from 1,982 individuals over three time periods as detailed in Table 1. Sera were collected from an age range of o to 89 years and stratified by birth cohorts. The 1,982 sera were grouped into panels according to time of serum sample collection (Table 1).

A small additional panel of anonymised children and adult sera before and after vaccination with 2010/11 trivalent inactivated influenza vaccine (TIV) was used to asses levels of vaccine-induced cross-reactive antibodies in children (3-14 years-old; 24 pairs) and adults (20-77 years-old; 24 pairs).

\section{Viruses}

Antigenic characterisation of virus isolates was performed using $\mathrm{HI}$ assays [13]. Virus strains used for $\mathrm{H}_{3} \mathrm{~N}_{2}$ analysis were: $A /$ Perth/16/2009 (human $\mathrm{H}_{3} \mathrm{~N}_{2}$ virus, circulating from 2009 onwards); $A$ / Wuhan/359/1995 (human $\mathrm{H}_{3} \mathrm{~N}_{2}$ virus, circulating from the mid-1990s); A/Swine/Minnesota/593/1999 (A/sw/ Minnesota/593/1999; genetic predecessor of swine $\mathrm{H}_{3} \mathrm{~N}_{2}$ viruses, which have recently caused limited human infection in North America, kindly provided by Prof I. Brown at the Veterinary Laboratory Agency, UK); and $A / P e n n s y l v a n i a / 14 / 2010$ and $A / I n d i a n a / 08 / 2011$ (swine $\mathrm{H}_{3} \mathrm{~N}_{2}$ viruses isolated from sporadic cases of human infection in the United States; both kindly provided by the World Health Organization Collaborating Centre (WHO CC) at the National Institute for Medical Research (NIMR), London, UK, who received the samples as part of the WHO Global Influenza Surveillance and Response System (GISRS) Pandemic Influenza Preparedness (PIP) Framework from the WHO CC at CDC, Atlanta), see also Table 2.
Viruses used for $\mathrm{H}_{1} \mathrm{~N}_{1}$ analysis were: NIBRG122 (reverse genetics virus of $A / E n g l a n d / 195 / 2009$, the influenza $A\left(\mathrm{H}_{1} \mathrm{~N}_{1}\right)$ pdmog UK prototype strain, provided by the National Institute for Biological Standards and Control (NIBSC)) and A/Aragon/RR3218/2008 (swine $\mathrm{H}_{1} \mathrm{~N}_{1}$ virus isolated from a sporadic human case in Spain in 2008 [12], kindly provided by the National Centre for Microbiology, Instituto de Salud Carlos III, Madrid, Spain).

The NIBRG122, A/Perth/16/2009, A/Wuhan/359/1995, A/Aragon/RR3218/2008, A/sw/Minnesota/593/1999 and $A / P e n n s y l v a n i a / 14 / 2010$ viruses were grown in embryonated hens' eggs. A/Indiana/08/2011 was cultured in MDCK cells.

\section{Serological methods and analysis}

Antibody titres were measured by $\mathrm{HI}[14,15]$. All assays were performed using turkey red blood cells (0.5\%), with the exception of the analysis with $\mathrm{A} /$ Perth/16/2009 virus, for which we used guinea pig red blood cells (0.5\%) according to WHO recommendation [16]. Undetectable titres ( 88 ) were assigned a value of 4. Age-related geometric mean titres (GMTs) with $95 \%$ confidence intervals $(\mathrm{Cl})$ as well as proportion of participants with $\mathrm{HI}$ titre $\geq 32$ (defined as seropositive) were calculated. Data were analysed by birth cohorts according to primary influenza exposure (before 1957, exposed to $\mathrm{H}_{1} \mathrm{~N}_{1} ; 1957-68$, exposed to $\mathrm{H}_{2} \mathrm{~N}_{2} ; 1968-99$ exposed to $\mathrm{H}_{3} \mathrm{~N}_{2}$; from 2000 onwards, representing the very young). Pearson's correlation coefficient $(r)$ was used to compare responses between $\log 10$ assay titres.

\section{TABLE 1}

Characteristics of serum panels for influenza serosusceptibility analysis, England, 2004-11 (n=1,982)

\begin{tabular}{|c|c|c|c|c|c|c|c|c|}
\hline \multirow[b]{2}{*}{ Panel name } & \multirow{2}{*}{$\begin{array}{l}\text { Time of } \\
\text { collection }\end{array}$} & \multicolumn{2}{|c|}{$\begin{array}{l}\text { Number of } \\
\text { samples }\end{array}$} & \multicolumn{3}{|c|}{ Age Ranges } & \multicolumn{2}{|c|}{ Analysed with } \\
\hline & & Total & $\begin{array}{l}\text { By } \\
\text { birth } \\
\text { cohort }\end{array}$ & Birth cohorts & $\begin{array}{l}\text { Age at } \\
\text { collection } \\
\text { (years) }\end{array}$ & $\begin{array}{l}\text { Year of } \\
\text { birth }\end{array}$ & $\mathrm{H}_{1} \mathrm{~N}_{1}$ subtype & $\mathrm{H}_{3} \mathrm{~N}_{2}$ subtype \\
\hline \multirow{4}{*}{2004 panel } & \multirow{4}{*}{ June 2004} & \multirow{4}{*}{687} & 176 & Pre-1957 & \multirow{4}{*}{$1-80$} & \multirow{4}{*}{$1924-2003$} & \multirow{4}{*}{$\begin{array}{l}\text { A/England/195/2009a, } \\
\text { A/Aragon/RR3218/2008 }\end{array}$} & \multirow{4}{*}{ Not analysed } \\
\hline & & & 87 & $1957-1967$ & & & & \\
\hline & & & 304 & 1968-1999 & & & & \\
\hline & & & 48 & After 2000 & & & & \\
\hline \multirow{4}{*}{2008 panel } & \multirow{4}{*}{$\begin{array}{l}\text { Jan } 2008 \\
\text { to April } \\
2009\end{array}$} & \multirow{4}{*}{1,179} & 588 & Pre-1957 & \multirow{4}{*}{$0-87$} & \multirow{4}{*}{$1921-2009$} & \multirow{4}{*}{ A/England/195/2009 } & \multirow{4}{*}{ Not analysed } \\
\hline & & & 67 & $1957-1967$ & & & & \\
\hline & & & 314 & 1968-1999 & & & & \\
\hline & & & 209 & After 2000 & & & & \\
\hline \multirow{4}{*}{2010 panel } & \multirow{4}{*}{$\begin{array}{l}\text { Autumn } \\
2010 \text { and } \\
\text { spring } \\
2011\end{array}$} & \multirow{4}{*}{116} & 33 & Pre-1957 & \multirow{4}{*}{$0-89$} & \multirow{4}{*}{$1922-2011$} & \multirow{4}{*}{$\begin{array}{l}\text { A/England/195/2009a, } \\
\text { A/Aragon/RR3218/2008 }\end{array}$} & \multirow{4}{*}{$\begin{array}{c}\text { A/Wuhan/359/95, } \\
\text { A/sw/Minnesota/593/99, } \\
\text { A/Pensylvania/14/10, } \\
\text { A/Indiana/08/2011, } \\
\text { A/Perth/16/09 }\end{array}$} \\
\hline & & & 13 & $1957-1967$ & & & & \\
\hline & & & 49 & 1968-1999 & & & & \\
\hline & & & 22 & After 2000 & & & & \\
\hline
\end{tabular}

${ }^{a}$ The reverse genetics derivative, NIBRG122, was used. 


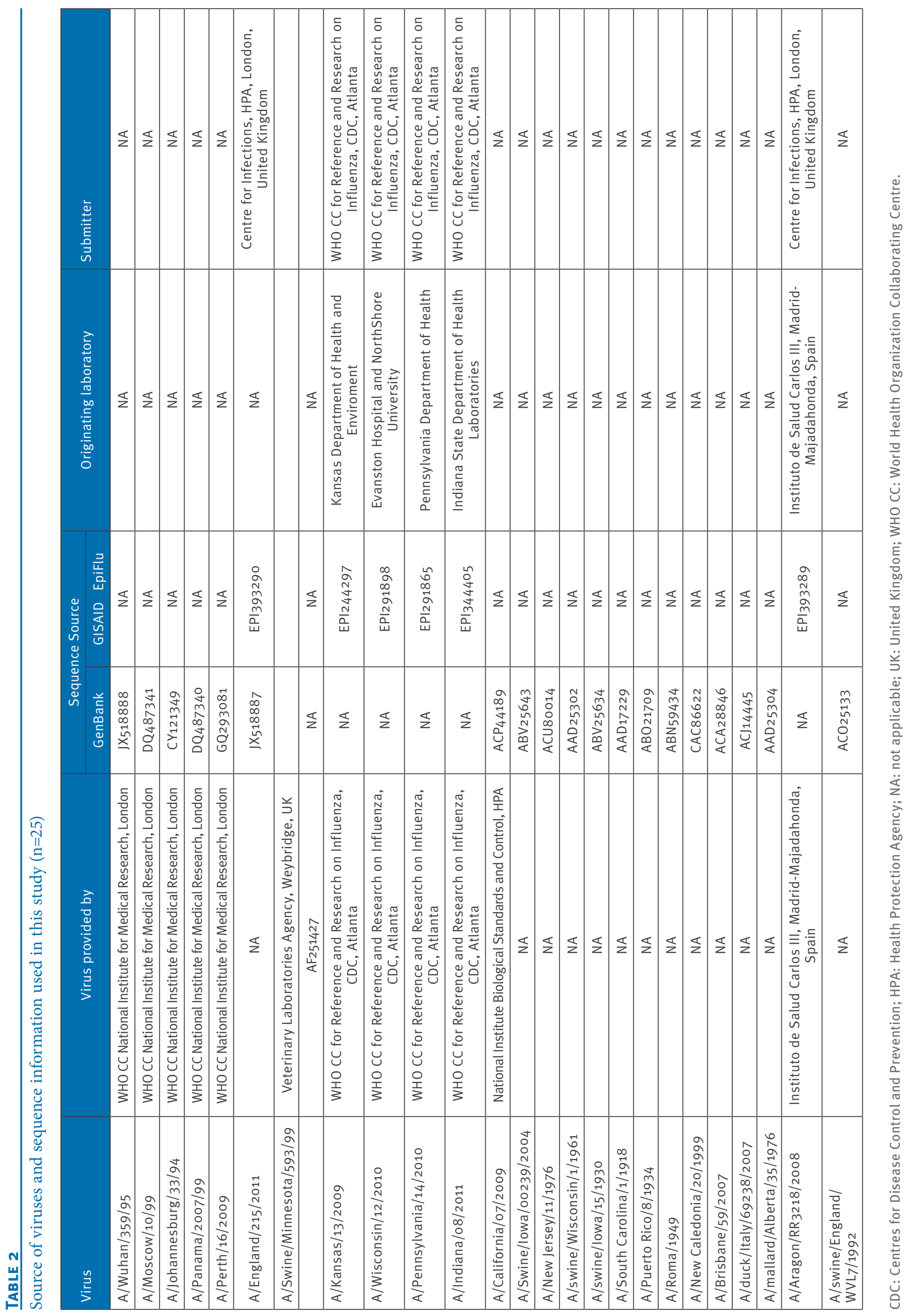


For analysis of vaccine sera, immunogenicity end points included group GMTs and geometric mean fold changes (GMTR) from pre- to post-vaccination with $95 \% \mathrm{Cl}$, the proportion of participants with $\mathrm{HI}$ titre 232 ('seroprotection rate' when evaluating vaccine antigens), and the proportion of seroconverting individuals ('seroconversion rate'; SCR); showing four-fold increase in post- compared with pre-immunisation titres or from $\mathrm{HI}$ titre $<8$ before immunisation to at least 32 after immunisation.

\section{Sequencing of full-length haemagglutinin}

and phylogenetic analysis

Virus RNA was extracted, underwent RT-PCR, and amplified products were sequenced $[13,17]$. Accession numbers for GenBank and the Global Initiative on Sharing All Influenza Data (GISAID) are listed in Table 2. Phylogenetic trees were constructed using deduced amino acid sequences with a neighbour-joining algorithm, available in the MEGA 4.0.1 software (http:// www.megasoftware.net).

\section{Results}

\section{Cross-reactivity of $\mathrm{H} 3 \mathrm{~N} 2$ viruses}

The classical swine lineage virus $\mathrm{A} / \mathrm{sw} /$ Minnesota/593/1999 showed some reactivity with ferret post-infection antiserum raised to human seasonal viruses from the mid-1990's, suggesting some antigenic similarity between swine and human viruses co-circulating during this period (Table 3 ).

Figure 1 shows the genetic relationships between haemagglutinin ( $\mathrm{HA}$ ) protein sequences of representative human $\mathrm{H}_{3} \mathrm{~N}_{2}$ and $\mathrm{sw}_{3} \mathrm{~N}_{2}$ lineages, including some from human infections with North American swine $\mathrm{H}_{3} \mathrm{~N}_{2}$ viruses detected since 2009. A/sw/Minnesota/593/99 clusters with human viruses from the mid-1990s, since this virus is a representative from the swine triple reassortant lineage that arose in 1998 and includes an HA gene from human origin. The human lineage further separates into two branches of viruses isolated before or after 1998.

Of 59 residues located at antigenic sites, current human and swine North American $\mathrm{H}_{3} \mathrm{~N}_{2}$ viruses differ at ca. 16 positions ( $73 \%$ identity at antigenic sites, $89 \%$ for the entire HA protein (data not shown). The highest pairwise identity between current North American swine viruses and human $\mathrm{H}_{3} \mathrm{~N}_{2}$ viruses included in this analysis is shown with $\mathrm{A} /$ Wuhan/359/95 (78-83\% identity at antigenic sites, $94 \%$ for the entire $\mathrm{HA}$ ), which is consistent with this virus being an ancestor for the $\mathrm{HA}$ segment of recent and classic North American $\mathrm{swH}_{3} \mathrm{~N}_{2}$ viruses.

Age stratified reactivity of human sera to seasonal $\mathrm{H}_{3} \mathrm{~N} 2$ viruses shows a profile consistent with exposure

\section{TABLE 3}

Antigenic analysis of influenza $\mathrm{A}(\mathrm{H} 3 \mathrm{~N} 2)$ viruses (seasonal, swH3N2 and swH3N2 variant influenza strains) ( $\mathrm{n}=11$ )

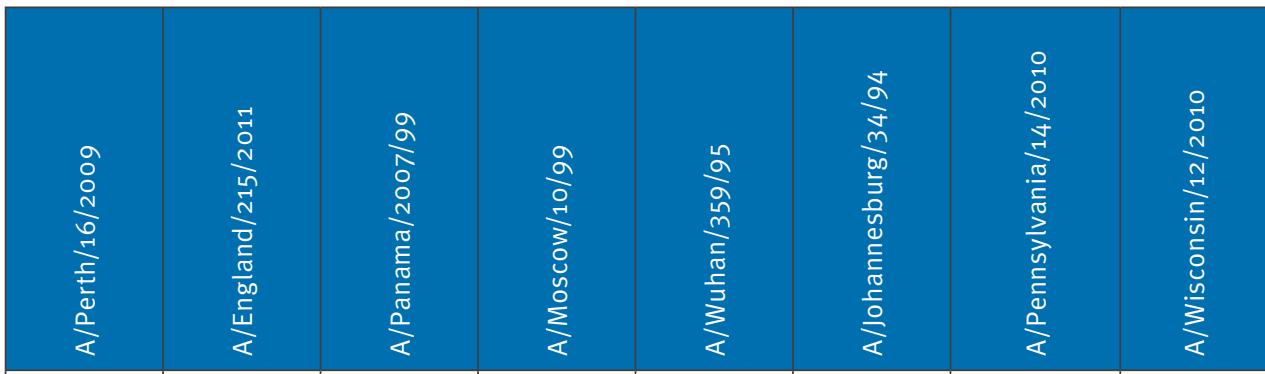

\begin{tabular}{|c|c|c|c|c|c|c|c|c|c|}
\hline & & $\mathrm{H}_{3} \mathrm{~N}_{2}$ & $\mathrm{H}_{3} \mathrm{~N}_{2}$ & $\mathrm{H}_{3} \mathrm{~N}_{2}$ & $\mathrm{H}_{3} \mathrm{~N}_{2}$ & $\mathrm{H}_{3} \mathrm{~N}_{2}$ & $\mathrm{H}_{3} \mathrm{~N}_{2}$ & $\mathrm{SwH}_{3} \mathrm{~N}_{2}$ & $\mathrm{SwH}_{3} \mathrm{~N}_{2}$ \\
\hline A/Perth/16/2009 & $\mathrm{H}_{3} \mathrm{~N}_{2}$ & 2,560 & 5,120 & $<$ & $<$ & $<$ & $<$ & $<$ & $<$ \\
\hline A/England/215/2011 & $\mathrm{H}_{3} \mathrm{~N}_{2}$ & 640 & 2,560 & $<$ & $<$ & $<$ & $<$ & $<$ & $<$ \\
\hline A/Panama/2007/99 & $\mathrm{H}_{3} \mathrm{~N}_{2}$ & $<$ & $<$ & 2,560 & 5,120 & 20 & $<$ & $<$ & $<$ \\
\hline A/Moscow/10/99 & $\mathrm{H}_{3} \mathrm{~N}_{2}$ & $<$ & $<$ & 1,280 & 10,240 & $<$ & $<$ & $<$ & $<$ \\
\hline A/Wuhan/359/95 & $\mathrm{H}_{3} \mathrm{~N}_{2}$ & $<$ & $<$ & $<$ & $<$ & 2,560 & 160 & $<$ & $<$ \\
\hline A/Johannesburg/33/94 & $\mathrm{H}_{3} \mathrm{~N}_{2}$ & $<$ & $<$ & $<$ & $<$ & $<$ & 2,560 & $<$ & $<$ \\
\hline A/Pennsylvania/14/2010 & $\mathrm{SwH}_{3} \mathrm{~N}_{2}$ & $<$ & $<$ & $<$ & $<$ & $<$ & $<$ & 5,120 & 2,560 \\
\hline A/Wisconsin/12/2010 & $\mathrm{swH}_{3} \mathrm{~N}_{2}$ & $<$ & $<$ & $<$ & $<$ & $<$ & $<$ & 640 & 2,560 \\
\hline A/Kansas/13/2009 & $\mathrm{swH}_{3} \mathrm{~N}_{2}$ & $<$ & $<$ & $<$ & $<$ & $<$ & $<$ & 2,560 & 320 \\
\hline A/Indiana/8/2011 & $\mathrm{sw}\left(\mathrm{H}_{3} \mathrm{~N}_{2}\right) \mathrm{v}$ & $<$ & $<$ & $<$ & $<$ & $<$ & $<$ & 2,560 & 5,120 \\
\hline A/sw/Minnesota/593/99 & $\mathrm{swH}_{3} \mathrm{~N}_{2}$ & $<$ & $<$ & $<$ & $<$ & 160 & 160 & $<$ & $<$ \\
\hline
\end{tabular}

$\mathrm{sw}\left(\mathrm{H}_{3} \mathrm{~N}_{2}\right) \mathrm{v}$ : variant of recent $\mathrm{swH}_{3} \mathrm{~N}_{2}$ viruses, which acquired the $M$ gene of the $\mathrm{A}\left(\mathrm{H}_{1} \mathrm{~N}_{1}\right)$ pdmog virus.

Haemagglutination inhibition titres for seasonal $\mathrm{H}_{3} \mathrm{~N}_{2}$ viruses, novel $\mathrm{sw}_{3} \mathrm{~N}_{2}$ viruses causing sporadic human infections, and sw $\mathrm{H}_{3} \mathrm{~N}_{2}$ viruses with post-infection ferret antiserum. $<$ denotes a titre $<40$. 
to different circulating strains according to birth cohort (Figure 2). Seropositivity with A/Perth/16/2009, the virus included in the TIV and the most recently circulating $\mathrm{H}_{3} \mathrm{~N}_{2}$ virus in England, shows the least variation across different ages. The youngest age cohort (born after 2000) and those born between 1957 and 1967 had the highest number of seropositive individuals to this strain, while younger adults born between 1968 and 1999 showed the highest number of seropositives to the previously circulating $\mathrm{H}_{3} \mathrm{~N}_{2}$ A/Wuhan/359/1995 virus.

Cross-reactive antibody levels to $\mathrm{swH}_{3} \mathrm{~N}_{2}$ viruses were lowest in children (born after 2000) and older adults (born before 1968) for the two viruses used in the analysis (Figure 2), with the lowest GMTs for the recent swine virus isolate $\mathrm{A} /$ Indiana/08/2011 (GMT=9; 95\% Cl: $\left.5^{-15}\right)$ found in the youngest age cohort. However, the two groups with lowest overall GMT seem to differ in susceptibility. We found significantly $(p=0.04$, Fisher's exact test) fewer seropositives in those 12 years-old and younger $(6 / 22=27 \%$ with $\mathrm{A} /$ Indiana/08/2011) compared to adults born before $1968(25 / 45=56 \%)$. Highest levels of cross-reactive antibodies to $\mathrm{swH}_{3} \mathrm{~N}_{2}$ strains were found in individuals born between 1968 and 1999. The susceptibility profile for the A/Wuhan/359/95 virus was very similar to that of an ancestor strain for swH3N2, A/sw/Minnesota/593/1999.

We observed the strongest correlation between $A$ / Wuhan/359/1995 and A/sw/Minnesota/593/1999 $(r=0.80)$ and weaker correlation between $\mathrm{A} /$ Wuhan/359/1995 and $\mathrm{A} /$ Indiana/08/2011 ( $r=0.69)$ as well as between $\mathrm{A} / \mathrm{sw} /$ Minnesota/593/1999 and $\mathrm{A} /$ Indiana/08/2011 viruses $(r=0.5)$. By contrast, we found no evidence for the pairwise correlations of antibody titres between A/Perth/16/2009 and any of the other $\mathrm{H}_{3} \mathrm{~N}_{2}$ strains used.

\section{FIGURE 2}

Reactivity in age-stratified sera to different influenza A(H3N2) viruses, England, 2010/11

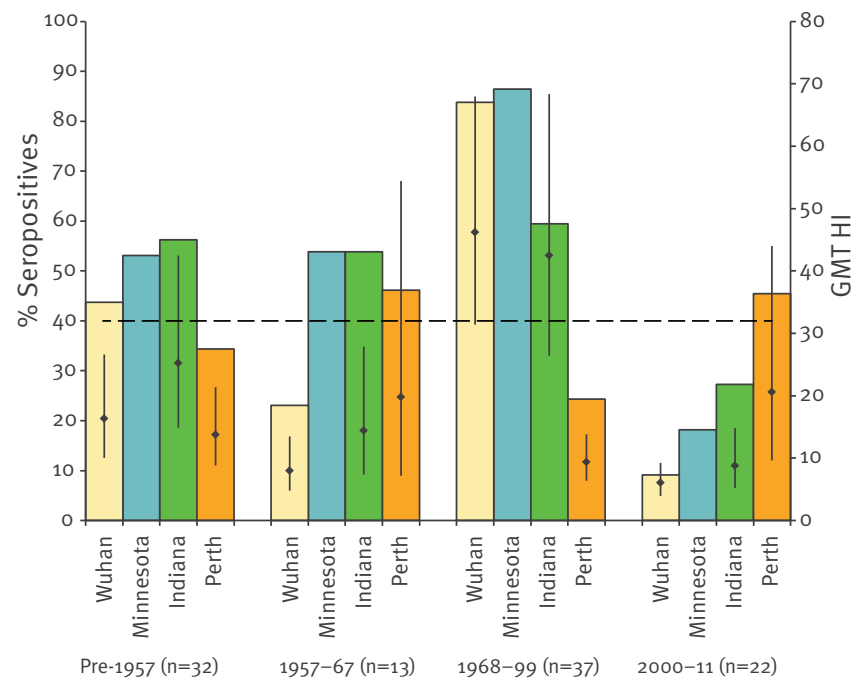

$\mathrm{Cl}$ : confidence interval; GMT: geometric mean titre; $\mathrm{HI}$ : haemagglutination inhibition.

Proportion with $\mathrm{HI}$ titre $\geq 32$ (\% seropositives) by exposure-related age group for influenza $\mathrm{A}\left(\mathrm{H}_{3} \mathrm{~N}_{2}\right)$ influenza viruses. The figure shows the results of the analysis of the 2010 panel (Table 1 ) with four influenza $A\left(\mathrm{H}_{3} \mathrm{~N}_{2}\right)$ viruses. The percentage of seropositives for the viruses are depicted in yellow for A/Wuhan/395/1995, blue for A/sw/Minnesota/593/1999, green for A/Indiana/08/2011 and orange for A/Perth/16/2009, while GMTs for analysis with A/Indiana/o8/2011, A/Wuhan/395/1995 and A/Perth/16/2009 are illustrated as diamonds in each bar with their $95 \% \mathrm{Cl}$ shown as vertical lines. Cut-off for seropositivity is shown as dotted line. Numbers of samples in each age group are given below the bars. Due to low available serum volume, $\mathrm{HI}$ with $\mathrm{A} / \mathrm{sw} /$ Minnesota/593/1999 virus was started at 1:16 dilution point for all samples and we could therefore not determine GMTs for this analysis.

\section{FIGURE 1}

Phylogenetic tree showing the relationship between human, swine and avian full length haemagglutinin sequences from influenza $\mathrm{A}(\mathrm{H} 3 \mathrm{~N} 2)$ viruses

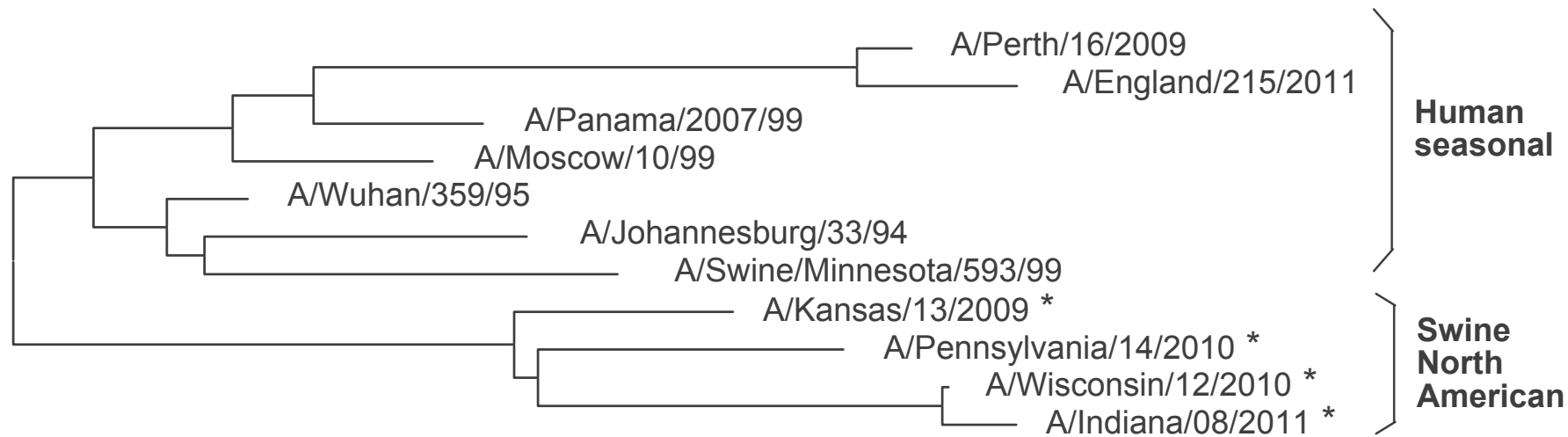


Cross-reactivity of influenza $\mathrm{A}(\mathrm{H} 1 \mathrm{N1})$ viruses

Ferret antiserum raised to human seasonal $\mathrm{H}_{1} \mathrm{~N}_{1}$ virus strains showed no cross-reactivity with viruses from either the classical or Eurasian swine lineages. The prototype $\mathrm{A}\left(\mathrm{H}_{1} \mathrm{~N}_{1}\right)$ pdmo9 virus $\mathrm{A} /$ California/7/2009 from the classical swine lineage showed no reactivity with antiserum raised to either human seasonal $\mathrm{H}_{1} \mathrm{~N}_{1}$ viruses or Eurasian swine viruses (data not shown and described elsewhere [18]). The recent Eurasian swine virus $A / A r a g o n / R R 3218 / 2008$, that caused one sporadic human infection in 2008 , had no reactivity with human seasonal virus antiserum.

Figure 3 shows the phylogenetic relationships between the HA sequences of representative human, swine and avian $\mathrm{H}_{1} \mathrm{~N}_{1}$ viruses isolated since 1918 . The pandemic virus $\mathrm{A} /$ California/07/2009 has its closest relationship with recent classical swine viruses, which have been circulating in North America and other regions since 1930 [19]. The branch most distal to A/California/7/2009 contains viruses isolated from pigs in Europe including A/Aragon/RR3218/2008, a swine virus isolated from a zoonotic infection in Spain. These viruses are closely grouped with $\mathrm{H}_{1} \mathrm{~N}_{1}$ viruses of avian origin. These so called Eurasian swine viruses have been circulating in swine since 1979 [20], were entirely derived from avian viruses, and have not yet been detected in North America. These observations clearly show that the HA gene from A/Aragon/RR3218/2008, an Eurasian avianlike swine virus, is genetically distant and has a different ancestor from the $\mathrm{A}\left(\mathrm{H}_{1} \mathrm{~N}_{1}\right)$ pdmog virus than their swine counterpart (classical swine lineage) circulating in North America. The observed lack of antigenic relatedness between A/Aragon/RR3218/2008 and the $A\left(H_{1} N_{1}\right) p d m o 9$ virus is further supported by the fact that, out of 50 residues located at antigenic sites, the two viruses differ at 16 positions ( $74 \%$ identity for the entire HA gene). Only antigenic site $\mathrm{Sa}$ is conserved between them. These findings also reveal that, for $\mathrm{H}_{1} \mathrm{~N}_{1}$ viruses, amino acid differences are present throughout the $\mathrm{HA}$, unlike current swine and human $\mathrm{H}_{3} \mathrm{~N}_{2}$ viruses, where divergence is located mostly at antigenic sites. Whole-genome analysis showed sequence identities around $80-85 \%$ between PB2, PB1, PA, NP and NS genes of $A / C a l i f o r n i a / 7 / 2009$ and A/Aragon/ RR3218/2008.

We compared antibody levels in panels collected at different time points (Figure 4 ). Cross-reactive antibody levels to $\mathrm{H}_{1} \mathrm{~N}_{1}$ viruses depended on the collection period. In 2004 (2004 panel), antibody levels to influenza $A\left(\mathrm{H}_{1} \mathrm{~N}_{1}\right)$ pdmog virus were lowest in individuals born after 1999 and highest in individuals aged 37 to 47 at the time (born between 1957 and 1967). After the 2007/08 winter (2008 panel), dominated by influenza $A\left(\mathrm{H}_{1} \mathrm{~N}_{1}\right)$ virus circulation, all age groups showed increases in reactive antibody levels to $A\left(\mathrm{H}_{1} \mathrm{~N}_{1}\right)$ pdmo9 virus. This was most evident in those born before 1957 , whilst only moderate increases were observed in those born between 1957-99, and the smallest increase noticed in the youngest age group. After the emergence and wide circulation of the $A\left(\mathrm{H}_{1} \mathrm{~N}_{1}\right)$ pdmog virus (2010 panel), significant increases in antibody levels to this virus were observed in all age groups. The youngest age groups had the highest titres overall (GMT=124, $95 \% \mathrm{Cl}: 65-236)$ against this virus and the highest percentage of seropositive individuals (91\%), while the number of seropositives in the older age groups was at least $45 \%$ even in the group with the lowest percentage overall, those born before 1957.

\section{FIGURE 3}

Phylogenetic tree showing the relationship between human, swine and avian full length haemagglutinin sequences from influenza $\mathrm{A}(\mathrm{H} 1 \mathrm{~N} 1)$ viruses

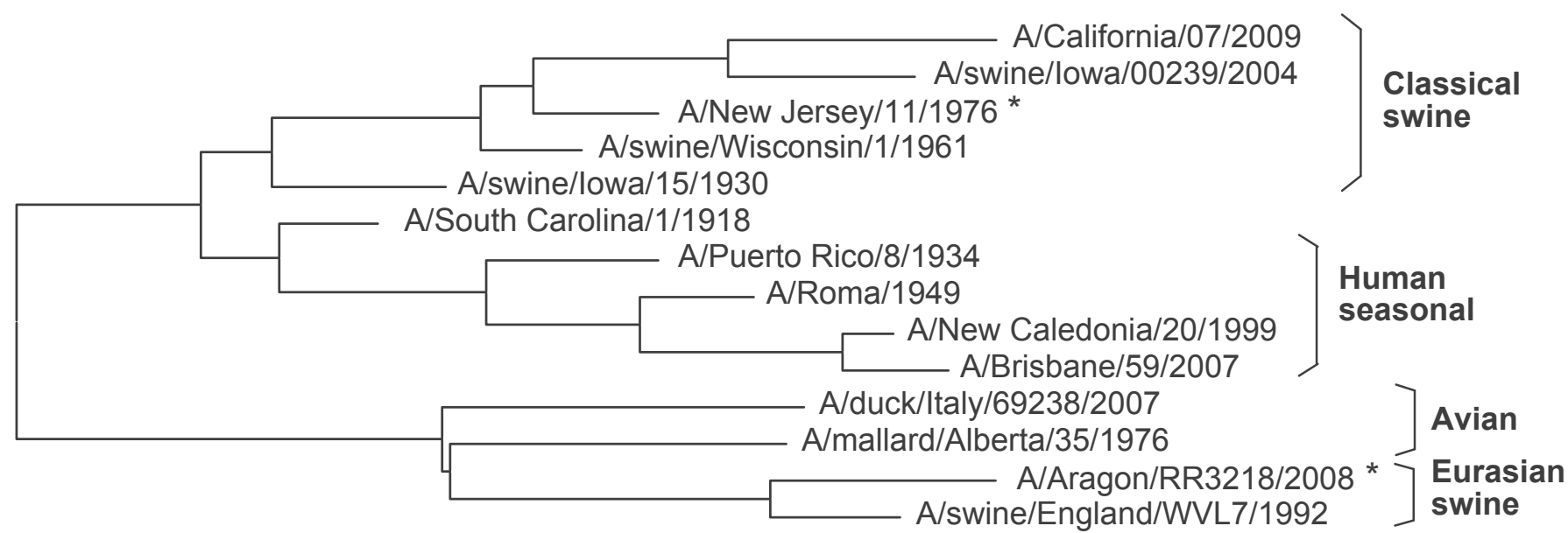


In contrast, we did not identify substantial timedependent changes of cross-reactive antibody to the A/Aragon/RR3218/2008 strain in 2004 and 2010 panels, and age-related seropositivity suggests high level of susceptibility in all age groups.

\section{Response to trivalent influenza vaccines}

Analysis of a small additional panel of anonymised children (3-14 years-old; 24 pairs) and adult sera (20-77 years-old; 24 pairs) before and after vaccination with 2010/11 trivalent inactivated influenza vaccine, showed that children had higher levels of antibody to currently circulating influenza A strains prior to vaccination, which was consistent with our age-stratified cohort analysis, while no significant differences were identified between children and adults for the influenza $B$ component of the TIV (data not shown).

\section{FIGURE 4}

Reactivity in age-stratified sera to influenza A(H1N1) viruses, England, 2004-11

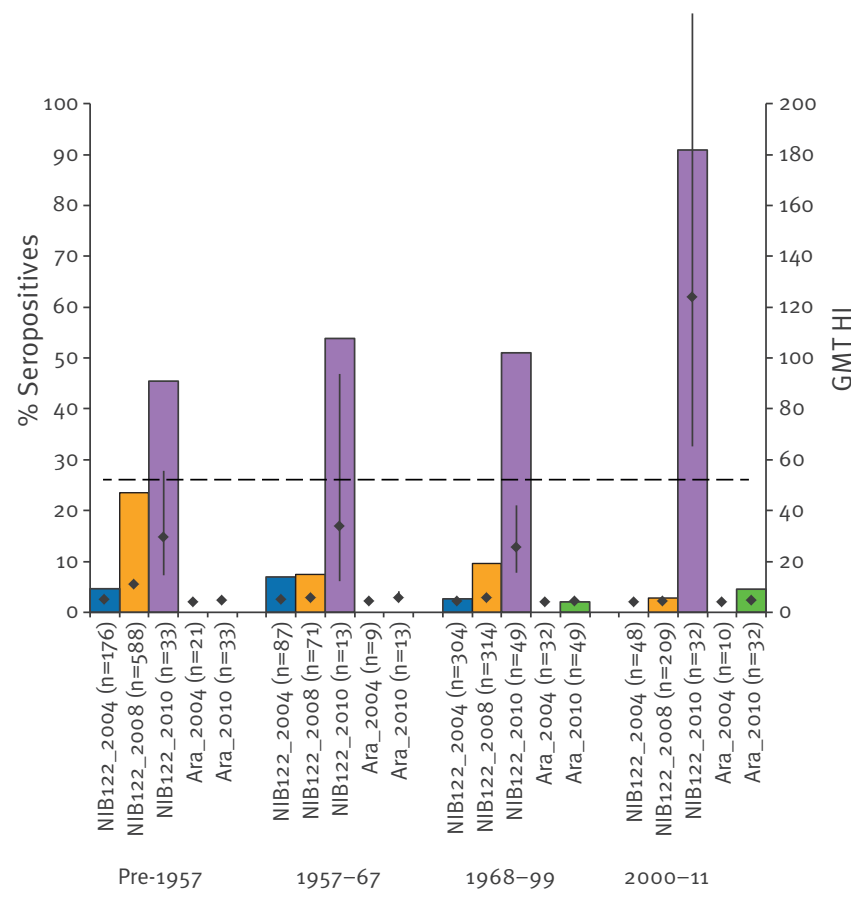

$\mathrm{Cl}$ : confidence interval; $\mathrm{GMT}$ : geometric mean titre; $\mathrm{HI}$ : haemagglutination inhibition.

Proportion with $\mathrm{HI}$ titre $\geq 32$ (\% seropositives) and GMT $(95 \% \mathrm{Cl})$ by exposure-related age group for $\mathrm{H}_{1} \mathrm{~N}_{1}$ influenza viruses. The figure shows the analysis of three serum panels, collected at different time points (Table 1$)$ with two influenza $A\left(\mathrm{H}_{1} \mathrm{~N}_{1}\right)$ viruses. The colouring of the bars indicates, which serum panel and virus were used in an analysis: the percentage of seropositives for the analysis with the NIBRG122 virus (reverse genetics derivative of A/ England/195/2009) are indicated in blue (2004 panel), white (2008 panel) and green (2010 panel), while purple bars were used for the analysis with A/Aragon/R3128/2008 of 2010 panel (percentage of seropositives for analysis with A/Aragon/R3128/2008 in the 2004 panel is zero for all four age cohorts). The GMTs for the analysis with the NIBRG122 and A/Aragon/RR3128/2008 viruses are illustrated as diamonds in each bar with their $95 \% \mathrm{Cl}$ shown as vertical lines. Numbers under bars represent the number of samples in each age group. Cut-off for seropositivity is shown as dotted tine.
For influenza $\mathrm{A}\left(\mathrm{H}_{3} \mathrm{~N}_{2}\right)$ viruses, we observed in children higher pre-vaccine GMTs with the currently circulating seasonal strain A/Perth/16/2009 (GMT=27; 95\% $\mathrm{Cl}$ : 13-55) and four to five times lower titres to recent $\mathrm{swH}_{3} \mathrm{~N}_{2}$ viruses (A/Pensylvania/14/2010) and $\mathrm{A} /$ Wuhan/359/1995, while adults had higher titres to $A /$ Pensylvania/14/2010 and A/Wuhan/359/1995 (GMT=40 and $34 ; 95 \% \mathrm{Cl}: 21-74$ and $19-60$, respectively), but significantly lower titres to A/Perth/16/2009. Children and adults showed comparable titre increases post vaccination, which were highest for the vaccine virus A/Perth/16/2009 (11.8 and 8.6-fold; 95\% Cl: 7.3-19.1 and 4.3-17.2, respectively). In both, GMTRs to A/ Pensylvania/14/2010 and $A /$ Wuhan/359/1995 viruses were three to four times lower than responses to $A$ / Perth/16/2009. The seroconversion rates were generally higher in children than in adults; in both, rates with the vaccine virus $A / P e r t h / 16 / 2009$ were almost twice as high as with the A/Pensylvania/14/2010 and A/Wuhan/359/1995 viruses.

For influenza $A\left(\mathrm{H}_{1} \mathrm{~N}_{1}\right)$ viruses, we observed clear differences in pre-vaccine titres for the currently circulating A/California/7/2009 virus, which were highest in children (GMT=76; 95\% Cl: 45-130) and significantly lower in adults (GMT=9;95\% Cl: 5-16). Both age groups had only negligible titres against the A/Aragon/RR3218/2008. Comparing responses to $\mathrm{A} /$ California/7/2009 and cross-reactive antibody responses to A/Aragon/RR3218/2008 viruses, similar SCRs and GMTRs for both age groups were observed with the vaccine strain $(S C R=96$ and 63; $G M T R=17.4$ and 13.1 , for children and adults respectively), while we observed two- to threefold lower SCR and six- to eightfold lower post-vaccine GMTRs with A/Aragon/ RR3218/2008 virus.

\section{Discussion}

For our serological analysis, we chose three swine influenza isolates from the United States (US) representative of the recent limited human-to-human transmission of $\mathrm{swH}_{3} \mathrm{~N}_{2}$ viruses in the US, together with historic and recent seasonal $\mathrm{H}_{3} \mathrm{~N}_{2}$ strains. The $\mathrm{swH}_{3} \mathrm{~N}_{2}$ viruses included an early isolate, A/sw/Minnesota/593/1999, closely resembling the ancestry of $\mathrm{swH}_{3} \mathrm{~N}_{2}$ strains, which began circulating in North American pigs in 1998 [21], as well as two strains isolated from recent human cases A/Pennsylvania/14/2010 and A/Indiana/o8/2011, the latter of which had acquired one of the eight gene segments ( $M$ gene) from the influenza $A\left(\mathrm{H}_{1} \mathrm{~N}_{1}\right)$ pdmo9 virus $[10,22]$. We also selected a swine influenza $\mathrm{A}\left(\mathrm{H}_{1} \mathrm{~N}_{1}\right)$ strain which had caused a sporadic human infection in 2008 in Spain [12] and compared serological responses with those to the $A\left(\mathrm{H}_{1} \mathrm{~N}_{1}\right)$ pdmog virus. The diversity of these swine viruses was shown both in genetic analysis and antigenic characterisation.

\section{Analysis of susceptibility to influenza $A(H 3 N 2)$ swine viruses}

We found little evidence for reactive antibodies to North American $\mathrm{swH}_{3} \mathrm{~N}_{2}$ viruses in children born in 
England after 1999, despite moderate levels of antibody to the recent circulating human A/Perth/16/2009 $\mathrm{H}_{3} \mathrm{~N}_{2}$ strain. This strongly suggests susceptibility of this age group to infection with North American $\mathrm{swH}_{3} \mathrm{~N}_{2}$ virus. These data predict a high attack rate and greatest impact in young age groups, if these $\mathrm{swH}_{3} \mathrm{~N}_{2}$ viruses were to emerge as a novel pandemic strain, analogous to the $\mathrm{A}\left(\mathrm{H}_{1} \mathrm{~N}_{1}\right)$ pdmog virus. The data are consistent with recently published results from the US [23], Canada [24] and Norway [25], and the observation that the cases identified so far have been mainly in children (ca. 90\% in individuals younger than 18 years) $[22,26]$. They also suggest antibodies induced to the most recently circulating human $\mathrm{H}_{3} \mathrm{~N}_{2}$ strains lack cross-reactivity with the investigated North American $\mathrm{SwH}_{3} \mathrm{~N}_{2}$ viruses.

Individuals born between 1968 and 1999 (aged 13-44 years in 2012) had the highest level of antibody to $\mathrm{SwH}_{3} \mathrm{~N}_{2}$ viruses, but the lowest level of antibody to the recent $\mathrm{H}_{3} \mathrm{~N}_{2}$ seasonal A/Perth/16/2009 strain. This also supports the conclusion that antibody reactive with $\mathrm{swH}_{3} \mathrm{~N}_{2}$ viruses occurs as a result of exposure to older $\mathrm{H}_{3} \mathrm{~N}_{2}$ strains, either because of antigenic relatedness of older $\mathrm{H}_{3} \mathrm{~N}_{2}$ strains to $\mathrm{swH}_{3} \mathrm{~N}_{2}$ viruses or because of an increase in cross-reactive antibodies induced with increasing age. Cross-reactive antibodies in humans seem to correlate with exposure to $\mathrm{H}_{3} \mathrm{~N}_{2}$ viruses circulating during the 1990 s (e.g. A/Wuhan/359/1995 virus). We assume that cross-reactive antibodies in those born between 1968 and 1999 reflect extensive exposure to $\mathrm{H}_{3} \mathrm{~N}_{2}$ variants circulating in that period and conform to previous observations that the highest attack rates following emergence of antigenic drift variants occur in the youngest age groups. Similar to surveillance data from the US [27] for the last two decades, variants of influenza $\mathrm{A}\left(\mathrm{H}_{3} \mathrm{~N}_{2}\right)$ were the most commonly circulating strains in Western Europe with multiple drift variants recognised during this period [28-30]. Together, this suggests that the cumulative antibody responses to these $\mathrm{H}_{3} \mathrm{~N}_{2}$ variants are a consequence of crossreactivity to $\mathrm{SwH}_{3} \mathrm{~N}_{2}$ viruses, rather than arising from recent exposure to A/Perth/16/2009.

The data also suggest the importance of priming with an antigenically closely matched virus for later protection from a drifted strain - similar to observations in the 2009 pandemic, where individuals which had been exposed to historic $\mathrm{H}_{1} \mathrm{~N}_{1}$ strains (dating from 1918 to 1956) early in their life seemed to be protected from infection with $\mathrm{A}\left(\mathrm{H}_{1} \mathrm{~N}_{1}\right)$ pdmog [14].

The assumption that cross-reactive antibody levels correlate with exposure to $\mathrm{H}_{3} \mathrm{~N}_{2}$ viruses circulating during the 1990 s is supported by the results from phylogenetic analysis (Figure 1) and antigenictiy work in ferrets (Table 3), which together point to similarity of seasonal human viruses of the $1990 \mathrm{~s}$ and the $\mathrm{swH}_{3} \mathrm{~N}_{2}$ viruses causing the recent zoonotic cases in the US. One of the influenza strains used in this study (A/Swine/ Minnesota/593/1999) dates back to the emergence of influenza $\mathrm{A}\left(\mathrm{H}_{3} \mathrm{~N}_{2}\right)$ in North American pigs and predates antigenic drift resulting from continuous circulation in pig herds. This isolate shares antigenic epitopes with human $\mathrm{H}_{3} \mathrm{~N}_{2}$ viruses circulating at the same time, such as $A /$ Wuhan/359/1995. We observed a close match of seroreactivity with A/Wuhan/359/1995 and A/ Swine/Minnesota/593/1999 viruses.

In individuals born before 1968 (aged 44 years and older in 2012), antibody titres to A/Perth/16/2009 were of similar level, indicating a similar overall exposure to a recently circulating variant. However, compared to antibody levels in individuals in the 1957-67 birth cohort, we observed lower reactivity with $\mathrm{swH}_{3} \mathrm{~N}_{2}$ viruses and A/Wuhan/359/1995 in these older adults despite greater likelihood of cumulative exposure to influenza $A\left(\mathrm{H}_{3} \mathrm{~N}_{2}\right)$ viruses. We assume that lower levels of cross-reactive antibody to $\mathrm{swH}_{3} \mathrm{~N}_{2}$ in these individuals could be a result of priming with $\mathrm{H}_{3} \mathrm{~N}_{2}$ viruses which emerged during the pandemic 1968, or childhood exposure to other, non- $\mathrm{H}_{3}$ influenza subtypes as suggested elsewhere [24]. Nevertheless, the overall GMTs suggest that significant numbers of individuals in England (ca. $50 \%$ ) may currently be protected from $\mathrm{swH}_{3} \mathrm{~N}_{2}$ infection.

We also determined the ability of pre- and post-immunisation sera from children and adults immunised with 2010/11 TIV to react with viruses of swine origin as a measure of whether vaccination with seasonal influenza vaccines produces cross-reactive antibodies capable of providing partial protection to emerging zoonotic swine influenza infections. Vaccination with contemporary TIV shows clear evidence of boosting reactivity to $\mathrm{SWH}_{3} \mathrm{~N}_{2}$ viruses after seasonal influenza vaccination. Although boosting was equally efficient in children and adults, vaccination is likely to be most beneficial to the younger age groups because of their generally lower cross-reactive baseline titres.

\section{Analysis of susceptibility to influenza \\ A(H1N1) European swine viruses}

We found no evidence of significant pre-existing immunity to a recent Eurasian $\mathrm{SWH}_{1} \mathrm{~N}_{1}$ isolate (A/Aragon/ RR3218/2008) in any age group (Figure 4). These findings are consistent with the substantial genetic (Figure 3 ) and antigenic divergence of this virus from the previous seasonal and current $A\left(\mathrm{H}_{1} \mathrm{~N}_{1}\right)$ pdmog viruses. Baseline immunity analysis in 2009 [14] together with influenza surveillance data [31] point at the importance of priming with historic seasonal $\mathrm{H}_{1} \mathrm{~N}_{1}$ strains for protection from infection with a newly emerging virus, i.e. $A\left(\mathrm{H}_{1} \mathrm{~N}_{1}\right)$ pdmog [32]. In contrast, the genetic and antigenic divergence of previous and current seasonal $\mathrm{H}_{1} \mathrm{~N}_{1}$ viruses as compared to the Eurasian SWH1N 1 points to a lack of priming in the English population.

However, whole genome sequencing data show that this virus has NA and $M$ genes which are similar to those of the $\mathrm{A}\left(\mathrm{H}_{1} \mathrm{~N}_{1}\right)$ pdmog virus, with $90 \%$ and $94 \%$ of sequence identity, respectively, consistent with the 
finding that these genes in the 2009 pandemic viruses had originated from the Eurasian lineage of swine viruses [33]. Vaccination with contemporary TIV shows only a limited boosting effect on antibody levels to A/ Aragon/RR3218/2008 in both children and adults, and could indicate an inability of current commercial vaccines to protect against $\mathrm{swH}_{1} \mathrm{~N}_{1}$ iviruses of the Eurasian lineage.

Our study has several limitations. We used a cut-off value of titres $\geq 32$, while it is unclear whether this titre would indeed confer protection on an individual level, especially for zoonotic infections to which whole populations are immunologically naïve.

This analysis is based on HI data. It has been speculated that neutralisation assays are more likely to detect antibody arising from previous exposure or vaccinations with related strains, which are undetectable by $\mathrm{HI}$ [34]. This could have resulted in an underestimation of cross-reactive antibodies. We are also unable to predict the possible contribution of cell-mediated responses to protection. Furthermore, our analysis was opportunistic and intended to be indicative. We used samples available to us, but had only limited numbers of samples with enough remaining volume for this analysis, as the material from the Public Health England serum archive had been used extensively for the UK seasonal seroepidemiology programme. As a result, the described serum panels vary significantly in sample number and the study was underpowered to detect significant differences between adults and children for the analysis of cross-reactive responses post TIV for vaccine trials or by birth cohort in the three population-based serosusceptibility panels (Table 1), especially with the low seroprevalence of antibodies to A/Aragon/RR3218/2008.

The analysis described here has been performed over a period of three years. An identical standard operating procedure was followed throughout; together with use of appropriate and consistent control sera, this should have kept variability of the results to a minimum and allow their comparability.

Although A/Wuhan/359/1995 seems to be an ancestor strain of the investigated $\mathrm{swH}_{3} \mathrm{~N}_{2}$ viruses, our antigenic characterisation (using ferret sera) indicates that it is not a precise antigenic match. However, seroprevalence data from our human cohort indicate that this virus might be closely related to a shared ancestor. Finally, for the $\mathrm{swH}_{1} \mathrm{~N}_{1}$ of the Eurasian lineage we selected only one isolate; it is possible that use of other strains might lead to slightly different conclusions regarding cross-protection. However, the phylogenetic data show that viruses in this lineage are significantly distant from previous seasonal $\mathrm{H}_{1} \mathrm{~N}_{1}$ viruses and the currently circulating $\mathrm{A}\left(\mathrm{H}_{1} \mathrm{~N}_{1}\right)$ pdmog viruses (Figure 3), suggesting that the observed lack of cross-reactivity is a universal feature for this group of viruses.

\section{Conclusions}

These data and the implied susceptibility to infection in different population subgroups highlight the importance of regular risk assessment of emerging swine origin viruses and virus-specific response planning. Vaccination and control strategies need to target individuals in society who appear to have least protection from infection. The observed differences in seroreactivity when analysing representative swine viruses from different geographical origin and two subtypes, both of which had recently caused infection in humans, emphasise the necessity of regular surveillance activities and interaction between animal and human health agencies.

The data presented here show that $\mathrm{swH}_{3} \mathrm{~N}_{2}$ and $\mathrm{swH}_{1} \mathrm{~N}_{1}$ subtypes have a different age-related pattern of potential susceptibility in the human population studied, which is again different from the variant $\mathrm{H}_{1} \mathrm{~N}_{1}$ subtype that caused the 2009 pandemic. Recommendations for pandemic preparedness need to be adjusted accordingly to take into account virus subtype and source of origin. At a global level, epidemiology of influenza virus in pigs is very complex and diverse. Similarly, recommendations for vaccination with TIV to induce cross-reactive antibody will depend on the nature of the emerging strain and age-dependent priming history in the population.

Globally, very few programmes exist that are based on interconnected animal and human health agencies. It is a clear recommendation from WHO that animal surveillance efforts should be enhanced beyond disease notification, with sharing of viruses between the human and animal sector to improve pandemic risk assessments [35].

\section{Acknowledgements}

The authors appreciate the helpful discussions during preparation of this manuscript with Nick Phin, John Watson, Alison Bermingham, Rod Daniels and John McCauley. We are grateful for the technical support provided by staff at the Respiratory Virus Unit: Janice Baldevarona, Surita Gangar, Paola Barbero and Dipa Lakhman.

HPA has received grant funding from Sanofi Pasteur, Baxter, CSL Ltd Australia and Roche. No other authors have competing interests to declare.

\section{References}

1. Garten RJ, Davis CT, Russell CA, Shu B, Lindstrom S, Balish $A$, et al. Antigenic and genetic characteristics of swineorigin $2009 \mathrm{~A}\left(\mathrm{H}_{1} \mathrm{~N}_{1}\right)$ influenza viruses circulating in humans Science. 2009;325(5937):197-201. http://dx.doi.org/10.1126/ science.1176225. PMid:19465683. PMCid:PMC3250984.

2. Webster RG, Bean WJ, Gorman OT, Chambers TM, Kawaoka Y. Evolution and ecology of influenza A viruses. Microbiological reviews. 1992;56(1):152-79. PMid:1579108. PMCid:PMC372859.

3. Webby RJ, Swenson SL, Krauss SL, Gerrish PJ, Goyal SM, Webster RG. Evolution of swine $\mathrm{H}_{3} \mathrm{~N}_{2}$ influenza viruses in the United States. J Virol. 2000;74(18):8243-51. http://dx.doi. org/10.1128/JVI.74.18.8243-8251.2000. PMid:10954521. PMCid:PMC116332.

4. Webby RJ, Rossow K, Erickson G, Sims Y, Webster R. Multiple lineages of antigenically and genetically diverse influenza 
A virus co-circulate in the United States swine population. Virus Res. 2004;103(1-2):67-73. http://dx.doi.org/10.1016/j. virusres.2004.02.015. PMid:15163491.

5. Brown IH. The epidemiology and evolution of influenza viruses in pigs. Vet Microbiol. 2000;74(1-2):29-46. http://dx.doi. org/10.1016/S0378-1135(00)00164-4

6. Brown IH. History and Epidemiology of Swine Influenza in Europe. Curr Top Microbiol Immunol. 2013;370:133-46. http:// dx.doi.org/10.1007/82_2011_194. PMid:22234411.

7. Nelson M, Gramer M, Vincent A, Holmes EC. Global transmission of influenza viruses from humans to swine. J Gen Virol. 2012;93(Pt 10):2195-203. http://dx.doi.org/10.1099/ vir.0.044974-0. PMid:22791604.

8. Zhu H, Webby R, Lam TT, Smith DK, Peiris JS, Guan Y. History of Swine Influenza Viruses in Asia. Curr Top Microbiol Immunol. 2013;370:57-68. http://dx.doi.org/10.1007/82_2011_179. PMid:21948002.

9. Ali A, Khatri M, Wang L, Saif YM, Lee CW. Identification of swine $\mathrm{H}_{1} \mathrm{~N}_{2}$ /pandemic $\mathrm{H}_{1} \mathrm{~N}_{1}$ reassortant influenza virus in pigs, United States. Vet Microbiol. 2012;158(1-2):60-8. http://dx.doi. org/10.1016/j.vetmic.2012.02.014. PMid:22397932.

10. Centers for Disease Control and Prevention (CDC). Swine-origin influenza $\mathrm{A}\left(\mathrm{H}_{3} \mathrm{~N}_{2}\right)$ virus infection in two children--Indiana and Pennsylvania, July-August 2011. MMWR Morb Mortal Wkly Rep. 2011;60(35):1213-5. PMid:21900876.

11. World Health Organization (WHO). Summary of status of development and availability of variant influenza $\mathrm{A}\left(\mathrm{H}_{3} \mathrm{~N}_{2}\right)$ candidate vaccine viruses. Geneva: WHO; [Accessed 17 August 2012]. Available from: http://www.who.int/influenza/vaccines/ virus/candidates_reagents/summary_a_h3n2v_cvv_20120308. pdf

12. Adiego Sancho B, Ome-aca Terés M, Martínez Cuenca S, Rodrigo Val P, Sánchez Villanueva P, Casas I, et al. Human case of swine influenza $A\left(\mathrm{H}_{1} \mathrm{~N}_{1}\right)$, Aragon, Spain, November 2008. Euro Surveill. 2009;14(7):pii=19120. Available from: http:// www.eurosurveillance.org/ViewArticle.aspx?Articleld $=19120$

13. Galiano M, Agapow PM, Thompson C, Platt S, Underwood A, Ellis J, et al. Evolutionary pathways of the pandemic influenza A (H1N1) 2009 in the UK. PloS one. 2011;6(8):e23779. http:// dx.doi.org/10.1371/journal.pone.0023779. PMid:21887318. PMCid:PMC3161082.

14. Hardelid P, Andrews NJ, Hoschler K, Stanford E, Baguelin M, Waight PA, et al. Assessment of baseline age-specific antibody prevalence and incidence of infection to novel influenza A/ H1N1 2009. Health Technol Assess. 2010;14(55):115-92. PMid:21208549.

15. Ellis JS, Zambon MC. Molecular analysis of an outbreak of influenza in the United Kingdom. European journal of epidemiology. 1997;13(4):369-72. http://dx.doi. org/10.1023/A:1007391222905.

16. Barr IG, McCauley J, Cox N, Daniels R, Engelhardt OG, Fukuda K, et al. Epidemiological, antigenic and genetic characteristics of seasonal influenza $A\left(\mathrm{H}_{1} \mathrm{~N}_{1}\right), A\left(\mathrm{H}_{3} \mathrm{~N}_{2}\right)$ and $B$ influenza viruses: basis for the WHO recommendation on the composition of influenza vaccines for use in the 2009-2010 Northern Hemisphere season. Vaccine. 2010;28(5):115667. http://dx.doi.org/10.1016/j.vaccine.2009.11.043. PMid:20004635.

17. Galiano M, Johnson BF, Myers R, Ellis J, Daniels R, Zambon M. Fatal cases of influenza $\mathrm{A}\left(\mathrm{H}_{3} \mathrm{~N}_{2}\right)$ in children: insights from whole genome sequence analysis. PloS one. 2012;7(3):e33166. http://dx.doi.org/10.1371/journal.pone.0033166 PMid:22412998. PMCid:PMC3295814.

18. Yang H, Qiao C, Tang X, Chen Y, Xin X, Chen H. Human infection from avian-like influenza $A\left(\mathrm{H}_{1} \mathrm{~N}_{1}\right)$ viruses in pigs, China. Emerg Infect Dis. 2012;18(7):1144-46. http://dx.doi.org/10.3201/ eid1807.120009. PMid:22709385. PMCid:PMC3376805.

19. Shope RE. The Etiology of Swine Influenza. Science. 1931;73(1886):214-5. http://dx.doi.org/10.1126/ science.73.1886.214. PMid:17729823.

20. Pensaert M, Ottis K, Vandeputte J, Kaplan MM, Bachmann PA. Evidence for the natural transmission of influenza A virus from wild ducts to swine and its potential importance for man. Bull World Health Organ. 1981;59(1):75-8. PMid:6973418. PMCid:PMC2396022.

21. Vincent AL, Ma W, Lager KM, Janke BH, Richt JA. Swine influenza viruses a North American perspective. Advances in virus research. 2008;72:127-54. http://dx.doi.org/10.1016/ So065-3527(08)00403-X

22. Centers for Disease Control and Prevention (CDC). First $\mathrm{H}_{3} \mathrm{~N}_{2}$ Variant Virus Infection Reported For 2012. Atlanta: CDC; 12 April 2009. Available from: http://www.cdc.gov/flu/spotlights/ h3n2v-variant-utah.htm

23. Centers for Disease Control and Prevention (CDC). Antibodies cross-reactive to influenza $A\left(\mathrm{H}_{3} \mathrm{~N}_{2}\right)$ variant virus and impact of 2010-11 seasonal influenza vaccine on cross-reactive antibodies - United States. MMWR Morb Mort Wkly Rep. 2012;61(14):237-41. PMid:22495226

24. Skowronski DM, Janjua NZ, De Serres G, Purych D, Gilca $\mathrm{V}$, Scheifele DW, et al. Cross-reactive and vaccine-induced antibody to emerging swine influenza $A\left(\mathrm{H}_{3} \mathrm{~N}_{2}\right)$ v. J Infect Dis. 2012;206(12):1852-61. http://dx.doi.org/10.1093/infdis/jis50o. PMid:22872731.

25. Walen K, Kilander A, Dudman SG, Ramos-Ocao R, Hungnes $\mathrm{O}$. Age-dependent prevalence of antibodies cross-reactive to the influenza $\mathrm{A}\left(\mathrm{H}_{3} \mathrm{~N}_{2}\right)$ variant virus in sera collected in Norway in 2011. Euro Surveill. 2012;17(19):pii=20170. Available from: http://www.eurosurveillance.org/ViewArticle. aspx?Articleld=20170. PMid:22607964.

26. Centers for Disease Control and Prevention (CDC). Evaluation of Rapid Influenza Diagnostic Tests for Influenza A ( $\left.\mathrm{H}_{3} \mathrm{~N}_{2}\right)$ v Virus and Updated Case Count - United States, 2012. MMWR Morb Mortal Wkly Rep. 2012 Aug 17;61(32):619-21. PMid:22895386.

27. Nelson MI, Edelman L, Spiro DJ, Boyne AR, Bera J, Halpin R, et al. Molecular epidemiology of $A / H_{3} N_{2}$ and $A / H_{1} N_{1}$ influenza virus during a single epidemic season in the United States. PLoS Pathog. 2008;4(8):e1000133. http://dx.doi.org/10.1371/ journal.ppat.1000133. PMid:18725925.PMCid:PMC 2495036.

28. Lin YP, Gregory V, Bennett M, Hay A. Recent changes among human influenza viruses. Virus Res. 2004;103(12):47-52. http://dx.doi.org/10.1016/j.virusres.2004.02.011. PMid:15163487.

29. Bragstad K, Nielsen LP, Fomsgaard A. The evolution of human influenza A viruses from 1999 to 2006: a complete genome study. Virol J. 2008;5:40. http://dx.doi.org/10.1186/1743422X-5-40. PMid:18325125.PMCid:PMC2311284.

30. Paget J, Marquet R, Meijer A, van der Velden K. Influenza activity in Europe during eight seasons (1999-2007): an evaluation of the indicators used to measure activity and an assessment of the timing, length and course of peak activity (spread) across Europe. BMC Infect Dis. 2007;7:141. http://dx.doi.org/10.1186/1471-2334-7-141. PMid:18047685. PMCid:PMC2216029.

31. Health Protection Agency (HPA). Surveillance of influenza and other respiratory viruses in the UK. 2010-2011 report. London: HPA; May 2011. Available from: http://www.hpa.org.uk/webc/ HPAwebFile/HPAweb_C/1296687414154

32. Jacobs JH, Archer BN, Baker MG, Cowling BJ, Heffernan RT, Mercer G, et al. Searching for Sharp Drops in the Incidence of Pandemic A/H1 $\mathrm{N}_{1}$ Influenza by Single Year of Age. PloS one. 2012;7(8):e42328. http://dx.doi.org/10.1371/journal. pone.0042328. PMid:22876316. PMCid:PMC3410923.

33. Gibbs AJ, Armstrong JS, Downie JC. From where did the 2009 'swine-origin' influenza A virus $\left(\mathrm{H}_{1} \mathrm{~N}_{1}\right)$ emerge? Virol J. 2009;6:207. http://dx.doi.org/10.1186/1743-422X-6-207. PMid:19930669. PMCid:PMC2787513.

34. Remarque EJ, de Bruijn IA, Boersma WJ, Masurel N, Ligthart GJ. Altered antibody response to influenza $\mathrm{H}_{1} \mathrm{~N}_{1}$ vaccine in healthy elderly people as determined by HI, ELISA, and neutralization assay. J Med Virol. 1998;55(1):82-7. http://dx.doi.org/10.1002/ (SICI)1096-9071(199805)55:1<82::AID-JMV13〉3-0.CO;2-1.

35. Ampofo WK, Baylor N, Cobey S, Cox NJ, Daves S, Edwards $S$, et al. Improving influenza vaccine virus selection: report of a WHO informal consultation held at WHO headquarters, Geneva, Switzerland, 14-16 June 2010. Influenza Other Resp Viruses. 2012;6(2):142-52. http://dx.doi.org/10.1111/j.17502659.2011.00277.x. PMid:21819547. 